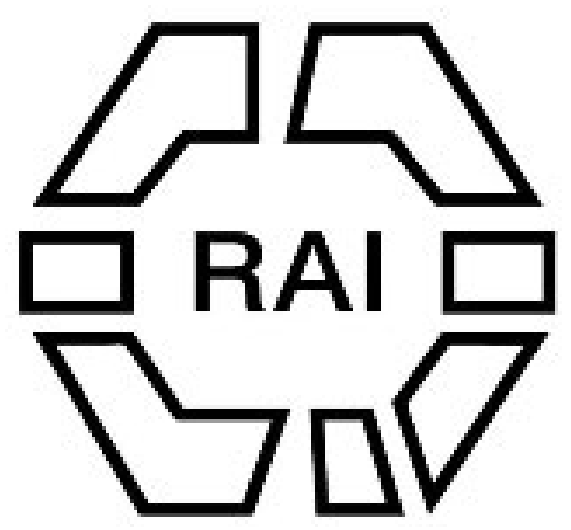

Papuans and Polynesians.

Author(s): George Brown

Source: The Tournal of the Anthropological Institute of Great Britain and Ireland, Vol. 16 (1887), pp. 311-327

Published by: Royal Anthropological Institute of Great Britain and Ireland

Stable URL: http://www.jstor.org/stable/2841520

Accessed: 14/06/2014 10:32

Your use of the JSTOR archive indicates your acceptance of the Terms \& Conditions of Use, available at http://www.jstor.org/page/info/about/policies/terms.jsp

JSTOR is a not-for-profit service that helps scholars, researchers, and students discover, use, and build upon a wide range of content in a trusted digital archive. We use information technology and tools to increase productivity and facilitate new forms of scholarship. For more information about JSTOR, please contact support@jstor.org. 
From the AUTHOR.-Zur Diskussion der die Hasenscharten und schrägen Gesichtsspalten betreffenden Vorträge der Herren Biondi und Morian. By Prof. Dr. Paul Albrecht.

"Herr Paul Albrecht zum letzten Male." Antwort auf den gleichnamigen Aufsatz des Herrn Geheimrathes Professor Dr. von Kölliker vom 12 August, 1885, in den Sitzungsberichten der Würzburger Physicalisch - medicinischen Gesellschaft vom Jahre 1885, von Prof. Dr. Paul Albrecht.

From the Academy. - Bulletin de l'Académie Impériale des Sciences de St. Pétersbourg. T. xxxi, No. 2.

- Boletin de la Academia Nacional de Ciencias en Cordoba. Tom. viii, Ent. 4.

Atti della Reale Accademia dei Lincei. Vol. II., Fas. 5, 6.

- Pamiegtnik Akademii Umiejetnosci w Krakowie, Wydzial Matematyczno-Przyrodniczy. Tom. $x$, xi.

From the Association.- Proceedings of the Geologists' Association. Vol. 9. No. 7.

From the Institute.-Proceedings of the Canadian Institute. No. 146.

From the Societr.-Journal of the Society of Arts. Nos. 17751777.

— Proceedings of the Royal Geographical Society. 1886. December.

- Proceedings of the American Philosophical Society. No. 123.

— Boletin da Sociedade de Geographia de Lisboa. 6a Serie. No. 5 .

From the Editor.--Nature. Nos. 891-893.

- Science. Nos. 197-198.

- Photographic Times. Nos. 269-272.

- American Antiquarian, 1886. November. Vol. viii. No. 6. L'Homme, 1886. Nos. 17, 18.

Matériaux pour l'Histoire primitive et naturelle de l'Homme. 1886. November.

The following paper was read in the author's absence by Dr. E. B. TyLoR, F.R.S.:-

\section{Papuans and Polynestans.}

By the Rev. George Brown.

Amongst the difficult questions of the day, are those of the original home of the races which inhabit Australia and the large groups of islands in the Pacific, and their affinity and identity with each other. They present such diversities of appearance, of language, and of customs, that the attempt to reduce them to 
a common type might almost be considered a hopeless one. The tendency, however, of anthropological science of the present day is to decrease the number of so-called special types in the Pacific. But opinions differ very much indeed as to the number of types to which the inhabitants of Australasia may be referred, and also as to the names by which they are to be distinguished.

The aboriginals of Australia present, perhaps, the greatest difficulty. Wallace, whilst maintaining that "the distinction that has been drawn between the Papuans proper and a special Melanesian type seems needless and fanciful," also declares that "the Papuan must not be identified with the Australian, the results of extensive philological researches being entirely opposed to such a conclusion." One must needs be careful when venturing to dissent from such a careful observer and writer as Mr. Wallace is; and I do not now maintain that the identity of Australians and Papuans can be proved. All that I wish to notice is, that the only proof which Mr. Wallace gives as a reason for his opinion, namely, that " the Australian idioms are characterised exclusively by suffix formations whereas the Papuan tongues shew a preference rather for prefixes, a fundamental difference altogether excluding any relationship between the two linguistic systems," is not borne out by our knowledge of Papuan dialects. I think Mr. Wallace has, in this instance, confounded the older Papuan with the later Polynesian language. The Papuan languages are all full of suffix formations; so that this "fundamental difference" at all events does not exist. It will be well, however, here to state what is one object of this present paper. For many years of my mission life I quietly accepted the old Malayo-Polynesian theory of the origin of the Polynesian races, and of course regarded the black frizzly-haired Melanesians or Papuans as constituting a radically distinct and separate race, with no identity in origin and little or no affinity in language. It was, however, my duty after spending some fourteen years in Samoa, to be stationed for some years amongst a purely Papuan people who were absolutely untouched by foreign influences, and whose language had never been reduced to a written form. A comparison of their language, manners, and customs, did much to shake my belief in old theories; and whatever position may be assigned to the Australian and Tasmanian races, I am pretty confident that there are no insuperable difficulties in classing the Papuan and Polynesian races under one general type, the Papuan constituting the older branch of the family. This is substantially the theory advanced by Mr. Wallace in his "Malay Archipelago," where, after describing the different races, he says (p. 592) "I 
believe, therefore, that the numerous intermediate forms that occur among the countless islands of the Pacific, are not merely the result of a mixture of these races, but are, to some extent, truly intermediate or transitional; and that the brown and the black, the Papuan, the natives of Gilolo and Ceram, the Fijian, the inhabitants of the Sandwich Islands, and those of New Zealand, are all varying forms of one great Oceanic or Polynesian race.

It is, however, quite possible, and perhaps probable, that the brown Polynesians were originally the produce of a mixture of Malays, or some lighter-coloured Mongol race with the dark Papuans; but if so, the intermingling took place at such a remote epoch, and has been so assisted by the continued influence of physical conditions and of natural selection, leading to the preservation of a special type suited to those conditions, that it has become a fixed and stable race with no signs of mongrelism, and showing such a decided preponderance of Papuan character, that it can best be classified as a modification of the Papuan type. The occurrence of a decider Malay element in the Polynesian languages, has evidently nothing to do with any such ancient physical connection. It is altogether a recent phenomenon, originating in the roaming habits of the chief Malay tribes; and this is proved by the fact that we find actual modern words of the Malay and Javanese languages in Polynesia, so little disguised by peculiarities of pronunciation as to be easily recognisable-not mere Malay roots, only to be detected by the elaborate researches of the philologist, as would certainly have been the case had their introduction been as remote as the origin of a very distinct race, a race as different from the Malay in mental and moral, as it is in physical, characters."

Mr. Wallace, in his "Australasia" has somewhat modified this opinion, and states (p. 261) "The editor of this volume has always maintained that the brown Polynesians are really quite distinct from the Malays, and, except in colour, seem to have more affinity with the dark woolly-haired races of the Pacific; or, which now seems more probable, are equally distinct from both." This view is supported by two writers who have great knowledge of the races and languages of the Pacific. The late Mr. W. S. W. Vaux, in a paper on the "Probable Origin of the Maories," read before the Anthropological Institute in 1876, maintains that there was once a distinct Polynesian language, and that the connection of the modern languages of the brown Polynesians with the Malay is by no means so intimate as many able philologists have asserted. Still more important and weighty is the evidence of Mr. W. L. Ranken, who, in a paper 
on the "South Sea Islanders," read before the same society a few months later, proposes the native term "Mahori" for the brown Polynesians, and shows that their language is totally distinct from the Malay, has a different construction, has very few Malay roots, and only a few quite recent Malay words. Though resembling Malays both physically and mentally in some respects, the Mahoris differ greatly from them in others. They have a much greater average height, their features are much more of the European type, and their hair is typically wavy. He traces this race to Samoa as their first home in the Pacific, but primarily from some part of the Asiatic continent. He says, "we are thus led to these conclusions; that they are of some kindred race to the Malays, of Mongolian stock; that they have separated from that stock as distinctly, and perhaps as early, as the Malays themselves, and always had a distinct language; that they dwelt some time in Papua, and perhaps in other lands of the Malay Archipelago, and there learnt some new words from Malay traders ; thence they migrated to Samoa, and have since colonised the South Sea, sometimes displacing Papuan settlers. In spreading northwards from Samoa they met another branch of their own family in the Kingsmill Islands, who had probably travelled along the Caroline Archipelago from the Philippines, and show another exodus of the same family about the same time. This convergence of the views of three modern writers, each starting from a different point and reasoning from a distinct set of observations, as to the radical distinctness of the Malays and the brown Polynesians will justify us in giving up the term Malayo-Polynesian as altogether misleading."

It is in my opinion unfortunate that Mr. Wallace did so modify his original theory. It will also be seen that I differ from Mr. Vaux and Mr. Ranken, principally on one point only, namely, that they, whilst maintaining that the Polynesian is distinct from the Malay, also maintain that he is radically distinct from the Papuan, whilst I maintain his original identity with that race.

Professor A. H. Keane, who, in "Nature," and in this Journal has contributed a good deal to the literature of this subject, divides these races into three families.

I. The dark races, which embrace-

(a) Australians.

(e) Negrito, as AEta, Samang, and Mincopies, or Andaman Islanders.

(i) Papuans, with east and west branches.

II. Brown, or Indo-Pacific races, embracing- 
(a) What has usually been called the Malayo-Polynesian race; but which he calls Mahori.

(e) Mikronesians.

(i) Malays proper.

Mr. Keane maintains ("Journ. Anthrop. Inst.," Vol. ix) that the difference in language and physical types of the brown races are far too varied to be derived from one stock; that there are elements in the Malay language and races absolutely nonexistent in those of the Eastern Pacific, while the Polynesian possesses characteristics of type and speech it could not have derived from the Malay. That Crawfurd is astray in assuming that the common linguistic element of all the brown people from Madagascar to Easter Island is not organic but of recent date, and borrowed from the Malay. On the contrary, this universal element is fundamental, pre-historic, a joint inheritance, coeval with the first dispersion, preserved more faithfully by the eastern branch than by the Malayan.

He declares that Mr. Wallace rightly separates the Malays from the Papuans, and connects them with the Mongolians.

"I substitute," he says, "for Malayo-Polynesian IndoPacific." He sums up his own conclusion as follows :-

I. Both of the great Asiatic types, the Caucasian and Mongolian have occupied the Indo-Chinese peninsula.

II. The brown races of Malaysia consist exclusively of these two elements variously intermingled, the Caucasian being the substratum.

III. The large brown Eastern Polynesian consists exclusively of the Caucasian element.

IV. Negrito Autochthones of Indo-Chinese and West Malayans, have been rather supplanted than absorbed by Caucasian and Mongolians.

V. The Papuan Autochthones of Eastern Malay and Western Polynesian have been absorbed rather than supplanted, the fusion producing Melanesians in the east, and Alfuros in the west.

Their movements were first south from Asia, then from the Archipelago east to the Pacific. The lighter races, the aggressors, extirpated the Negritos in Western Polynesia, but intermingled with the Papuans in the east.

There is no Malayan type. It is not a racial designation.

What relations are the brown Malaysian to the. brown Polynesian? His view is that the Caucasian Malayan broke away east at the same time as the arrival of the Mongolians, and that the Sawaiori are their descendants.

Prof. Keane also maintains, in the appendix to Wallace's 
"Australasia," that the Malayan is rather a modification of the Mahori (Polynesian) than the reverse (p. 611). He says the Mahori is a pure and unmixed race if any such is still to be found any where on the globe. Then to get rid of the difficulty found in the fact that the Mahoris have, as stated, almost certainly migrated from their present Malayan region eastward to their actual Pacific domain, he supposes the Eastern Archipelago to have been originally peopled by Polynesian races. In proof of this he describes Mantawey Islanders as pure Polynesians. The presence of the Mahori (Polynesian) people on the extreme western boundary of the Malayan dominion, cannot, he says, be accounted for by assuming a more recent migration across all the vast and often densely peopled Papuan and Malayan region, from Samoa westward to or beyond Sumatra. "Hence," he says, " the inevitable conclusion that these Manataweys are here autochthonous, possibly the only remnant of the Western Mahoris that has escaped contact and fusion with the intruding subMongolian and other Asiatic races. In short, the Mahoris went eastward, while the common speech was still everywhere in its present primitive state, and before, or possibly even in consequence of the eruptions from the north-eruptions modifying in the west the type which preserved its purity under exceptional circumstances in the east" (p. 613). In this latter idea he seems to agree with Fornander; but the great difference which exists between Mr. Keane, and those who think with Mr. Wallace, Mr. Wake, and others is, that he still adheres to his assertion that the Papuan and Polynesian (or Mahori as he calls them) constitute absolutely distinct and separate races.

Judge Fornander, of Hawaii, has written fully on the question, and his theory will be shown by the following extracts in which he sums up "I think the facts collected in the foregoing attempt to satisfactorily solve the question of the Polynesian origin, will warrant the conclusion that the various branches of that family, from New Zealand to the Hawaiian group, and from Easter Island to the outlying eastern portion of the Fiji Archipelago, are descended from a people that was agnate to, but far older than the Vedic family of the Arian race; that it entered India before these Vedic Arians ; that there it underwent a mixture with the Dravidian race, which, as in the case of the Vedic Arians themselves, has permanently affected its complexion; that there also, in greater or less degree, it became moulded to the Cushite-Arabian civilisation of that time; that, whether driven out of India by force, or voluntarily leaving for colonising purposes, it established itself in the Indian Archipelago at an early period, and spread itself from Sumatra to Timor and 
Luzon; that here the Cushite influence became paramount to such a degree as to completely engraft its own legends, myths, cult, and partially its institutions upon the folk-lore and customs of the Polynesians ; that it was followed in this Archipelago by Brahmanised or Buddhist Ario-Dravidians from the eastern coasts of Deccan, with a probably strong BurmahTibetan admixture, who, in their turn, but after protracted struggles, obtained the ascendency and drove the Polynesians to the mountain ranges and the interior of the larger islands, or compelled them to leave altogether; that no particular time can be assigned for leaving the Indian Archipelago and pushing into the Pacific, it may have occurred centuries before the present era, but was certainly not later than about the first century of it; that the diversity of features and complexion in the Polynesian family, the frequent broad forehead, Roman nose, light olive complexion, wavy and sometimes ruddy hair, attest as much its Arian descent and Cushite connection as its darker colour, its spreading nostrils, and its black eyes attest its Inixture with the Dravidian race; and, finally, that if the present Hindu is a Vedic descendant, the Polynesian is a fortiori a Vedic ancestor" (pp. 159, 160).

Mr. C. Staniland Wake is one of the more recent writers who combats Mr. Keane's opinions, and substantially agrees with Mr. Wallace in the most important points. Mr. Wake objects to Mr. Keane's definitions and classification, more especially as regards his first class of dark races, in which he includes Negritos, Papuans, and Australians. Wake argues that the great difference in the long straight hair of Australia, and the woolly and frizzly haired Negrito and Papuan is against this classification. Also that Australians and Papuans are fullbearded and Negritos are beardless, also Negritos are shortheaded and Papuans are long-headed. Wake then says ("Journ. Anthrop. Institute," vol. xii) "that it may be much doubted whether the Polynesians do not in reality possess as many features in common with the Papuans as with the Caucasian tribes of Indo-China" (p. 204); and a little further on he says "the existence of differences of no little importance between the Polynesian and Papuan is perfectly consistent with those races having been derived from a common stock." $\mathrm{He}$ attaches also great importance to the fact that in the Malay Archipelago are natives intermediate between the two, namely, Ceram, Bouru, \&c. Wallace, however, describes these Ceramese as undoubted Papuans (p. 401). Wake sums up as follows:-

1. The Eastern Archipelago was at a very early period inhabited by a straight-haired race belonging to the so-called VOL. XVI. 
Caucasian stock, the purest modern representatives of which are the Australians.

2. To this race belonged also ancestors of all the Oceanic races, including the Papuans, Micronesians, Tasmanians, and the Polynesians.

3 . The special peculiarities of the dark races are due to the introduction of various foreign elements, the Negritos having influenced all of them in varying degrees.

4. The lighter Oceanic races show traces of the Negrito influence; but they have been affected at various periods by intermixture with peoples from the Asiatic area, giving rise on the one hand to the so-called savage Malayan, and on the other to the Polynesians, who have been specially affected by the Malays.

5. Traces of an Arab or Semitic element are apparent among the dark and light Oceanic races, but chiefly among the Papuans and the Melanesians, the former of whom may also possess a Hindu admixture.

These conclusions probably require, as Mr. Keane supposes, the Negritos to have been the earliest inhabitants of the Eastern Archipelago; but there is less truth in Mr. Keane's further supposition, that this primitive race, spreading north over the Asiatic continent, became, under more temperate climes, different, first into the yellow Mongol, and then, through it, into the fair Caucasian type, returning in subsequent ages to its original home of Malays and Polynesians.

He then adverts to Whitmee's theory, "that not only are the whole of the Malayo-Polynesian languages, together with those of the Indian Archipelago and the Malagasy, more or less changed branches from an original root-stock, of which the Malay is more changed than any of the others; but that first the Papuan language and then the Australian must be affiliated to the same stock, the original form of which they approach still nearer to than either the Malay or the Polynesian branches." This opinion, which agrees with that of other competent authorities, coincides with my theory, and it would be no less strongly supported by a consideration of the manner and culture of the Oceanic races.

Keane replied to Wake, very strongly objecting to some of his conclusions. He said "the linguistic element, treated vicariously if not altogether ignored by Wake, possesses in this area quite an exceptional importance. Hence it could not be too widely known that after fuller research Von der Gabelentz had abandoned his former views and now held that the Papuan and Polynesian languages, like the races, were fundamentally distinct. In this conclusion Dr. A. B. Meyer acquiesced, and there 
could be little doubt that Mr. Codrington would agree with Mr. Whitmee that the two forms of speech had nothing in common beyond superficial resemblances, or what might be due to mutual borrowings."

A resumé of this may now be given. Wallace believes that these peoples are all varying forms of one great Oceanic or Polynesian race. Keane believes in two distinct races amongst the blacks, and that the Mahori, so far from being a modification of the Malay, is a pure language; and, as he thinks, the Malay is more probably a modification of the Mahori or Eastern Polynesian. He also maintains that the Papuan and Mahori are essentially and radically distinct races and languages.

Fornander believes that the Polynesians were the original inhabitants of Malaysia prior to the irruption of Malays; that they were driven out from there and so peopled Eastern Polynesia. He also maintains that the Papuan and Polynesian are distinct peoples.

Mr. Wake believes, as already quoted, that the Eastern Archipelago was once inhabited by a straight-haired race belonging to the so-called Caucasian stock, of which the aboriginal inhabitants of Australia are the purest modern representatives; that these were the ancestors of all these Papuan and Polynesian peoples, and that the special differences which exist amongst them are due to the introduction of various foreign elements, the Negritos having influenced all of them in varying degrees.

$\mathrm{He}$ accounts for the lighter races as having been specially affected by admixture with peoples from the Asiatic area, and so giving rise to the so-called "savage Malay," on the one hand, and to the Polynesian on the other ("Journ. Anthrop. Inst.," vol. xii.)

There are, of course, some other theories, such as that of Taylor (Te Ika a Maui) and others, that the Polynesians came from America, but I do not discuss them now.

My own opinion is that Mr. Wallace and Mr. Wake are very much nearer to the truth than any of the others. I cannot, however, now go into the question of the original habitat, and their Aryan or Turanian affinities. Though I think it will not be difficult to show that they have been affected by both races at different periods, I cannot decide the question either as to the first conclusion of Mr. Wake, that the Archipelago was originally peopled by a race of straight-haired blacks, of which the Australian black is the purest representative. There are many customs of these blacks very similar indeed to those of the Papuans of the Western Pacific, and I think that their 
language will certainly be found to be more closely connected with Papuan than with this later Polynesian.

I think it is extremely likely that there was originally one great race occupying these different groups, as far west at least as Borneo and probably extending upon the mainland on the side of Siam, the Malacca Peninsula, and perhaps as far as Burmah, which probably at that time formed part of one vast continent. The traces of these peoples are or have been found in all the different groups, from the black races found in New Zealand by the original Maori colonists, and who were derisively called by them "black kumara," to Western Malaysia, and also on the mainland. The Papuans of the present day are the purest representatives of this race. In Malaysia this pre-Malayan race was modified by admixture with the Turanian races of the mainland of Asia; and this constituted the present Polynesian race, which still retains so much of its old Papuan element. This intermixture will probably account for some if not all of the differences which exist to-day between the brown and the black races, as they are found on the different groups. At this period I think it likely that the migration eastwards set in, probably caused by the encroachments of Malay and Hindu immigrations as Fornander states. In fact, the principal difference between Mr. Fornander and myself is that I hold that the basis of the Polynesian is Papuan with Asiatic admixture; whilst he describes it simply as a separate and distinct anteMalayan race, which drove out the Papuan peoples only in turn to be themselves driven out by the Malays, and so compelled to look for other lands on which to settle.

\section{Names of Races and their Location.}

When we consider the great difference of opinion as to the original habitat and affinity or otherwise of these peoples, it will be no matter for surprise that a great difficulty has been found in fixing upon names for them which would describe the people without committing the writer to any particular theory. The names, in fact, are nearly as numerous as the theories have been and are. Malayo-Polynesia is virtually abandoned, however, by all parties. For the brown races the term Sawaiori, Mahori, and a lot of others, have been proposed; and an equal number also for the black races. It would scarcely be right here to enter into an explanation of the reasons why I do not employ any of these fanciful names. I shall use the term Eastern Polynesian or simply Polynesian, to represent the brown races wherever found, and the term Western Polynesian, Papuan, or Melanesian, to represent the black races of the Pacific, who are principally found now in a pure state only in the western groups. 
The Eastern Polynesian people inhabit, amongst other groups, Samoa, New Zealand, Friendly Islands, Niue, Ellice Group, the Hervey Group, Tahiti, Marquesas, Sandwich Islands, Marlagascar, and other smaller islands, some of which, such as Lord Howe's Group, Steward's Group, \&c., are found in very close proximity to islands peopled by pure Papuans.

The Western Polynesians inhabit New Guinea, New Britain, and New Ireland, Admiralty Groups, Solomons, Santa Cruz, New Hebrides, New Caledonia, and many other islands and parts of islancis outside of these areas.

The Eastern Polynesian may be described as of a light brown with varying shades of colour. Perhaps the best illustration is that of the colour of a cup of coffee, with the ordinary quantity of milk in it, perhaps a little brighter in colour and darker or lighter as the coffee may be made by the proportion of milk put into it.

The hair is curly or waved, not straight like that of the Malay. In fact, in Samoa, they call straight hair "lauulu valea" or foolish hair, an incidental mark, I think, of the survival of the old Papuan love for the large frizzly mops of hair, which in his opinion are so essential to beauty. The stature is fully equal to that of the ordinary European. They are a cheerful and joyous people, and fond of amusement. They have hereditary chiefs, descent is traced through the father, and also through the mother, especially if she is of higher rank than the father. The language is soft and musical, every syllable being open and no consonantal terminations. They have a great respect for rank, and this is often irrespective of the physical power, appearance, or wealth of the possessor. A good speaker will always command respect and attention, often far greater than that to which his rank would entitle him.

The Western Polynesian or Papuan is generally of a sooty brown or black colour, though this colour is said to vary in New Guinea from the black colour of the typical Papuan, to the light brown of the Polynesian. I may mention here also the fact that no two writers can agree in a description either of a typical Papuan or Polynesian, which of itself surely favours the presumption that they are not two absolutely distinct and separate races. The Papuan is frizzly-haired and full-bearded generally, though in this respect also the races differ very much from each other. $\mathrm{He}$ is generally tall and lanky, and not so well formed and developed as the Polynesian. There is no hereditary chieftainship, descent being through the mother only. In most islands, if not in all, there are class divisions which cannot intermarry in their respective classes. The Papuan, where unaffected by Polynesian admixture as in Fiji, pays but little attention to rank unless it is backed by physical power or by the possession of wealth, which 
may enable the possessor to do mischief. The language is very full and expressive; the dialects are as numerous almost as the tribes, every petty district on some islands having a separate and distinct dialect, which is often unintelligible to people living only a few miles away. These languages admit of consonantal terminations, and are many of them more agglutinating than those of Eastern Polynesia are found to be. These are only a few of the principal characteristics which may be observed, but it will be seen at once how difficult it is to describe the typical specimen of either race. I have only described some of the principal differences, but in order to show that there is a much closer affinity between the two races than is generally supposed, I will discuss some of these differences in detail.

\section{Language.}

Professor Keane's principal complaint against Mr. Wake's paper ("Journ. Anthrop. Inst.," vol. xii, p. 221) was that his arguments in favour of that essential difference of the two races as proved by their language had not been fairly dealt with; and he stated that the conclusion of his own paper was, that whatever might be the relationship of other stocks, the dark frizzly haired, hook-nosed, hypsistenocephalic Papuans of fully developed agglutinating speech, had no perceptible affinity, beyond their common manhood, to the tall brown, somewhat lank-haired, straight-nosed, brachycephalic Eastern Polynesians of almost isolating, or very faintly developed, agglutinating speech.

It would be out of place here to enter very fully into this matter. I can only state that after 14 years spent in the study of one of the purest and softest Eastern Polynesian dialects which is known, I went to live amongst a purely Papuan people, knowing absolutely nothing of these differences of opinion, and never having heard that any man in this world had ever questioned the fact that the two languages and the two races were absolutely and radically distinct and separate. There was no white man in the New Britain Group when I landed, and in fact most of the places had never been visiterl by either Europeans, Malayans, or Polynesians. The language had never been reduced to writing, and there were of course no interpreters. My first task was to learn the language as best I could; and afterwards to reduce it to a written form. In this we succeeded so far that we have now a vocabulary of at least 6,000 words, with a fair grammar of the language. The Gospel of St. Mark has been translated and printed, and is read intelligently by the natives. The gospel of St. Matthew has been translated and revised by the missionaries since I left the group, and is now ready for the press.

It was during my work of writing the grammar and vocabulary 
and translating that my opinions changed, and that I was led to believe that the differences which exist to-day in the language and customs of these people, so far from proving their absolute difference from each other, may be used to show that they are essentially the same. I was surprised to find not merely purely Eastern Polynesian words used to express identical meanings, but in our attempt to dig down into the heart of the language I unearthed Polynesian roots which, though not used to express the same shade of meaning, were employed to express one which was strictly analogous, if not absolutely identical. I am well aware that we cannot prove identity of origin from similarity in language, and also that the fact of a certain number of Malayan or of Eastern Polynesian words found in a Papuan language apart from any similarity in grammatical construction, by no means proves that they are derived from a common stock. But I purpose dealing with this part of the comparison first.

From a hasty comparison, I have selected some 170 words which all express similar meanings in different languages, namely Duke of York, a Papuan dialect, Samoa, which is said to be the original Hawaiki from which the Polynesians went forth, and Maori, which was one of the latest places colonized by them, The synonyms of the words found in Samoan or Maori would also, as is well known, be likewise found in almost every other Polynesian language.

Examples of Words used in the same Sense.

\begin{tabular}{|c|c|c|c|c|c|c|c|c|c|c|c|}
\hline \multicolumn{3}{|c|}{ English. } & \multicolumn{3}{|c|}{ Duke of York. } & \multicolumn{3}{|c|}{ Samoan. } & \multicolumn{2}{|l|}{ Maori. } & ous. \\
\hline Outrigg & & $\cdots$ & aman & & ... & ama & $\cdots$ & ... & ama & & ama, Tah. \\
\hline Canoe & $\ldots$ & ... & $\mathrm{a} k \mathrm{a}$ & $\ldots$ & ... & vaa & ... & ... & waka ... & $\cdots$ & vaka, Niue. \\
\hline Fish & $\ldots$ & ... & ain & $\ldots$ &.. & iá & ... & $\ldots$ & ika $\quad \ldots$ & $\cdots$ & ika, Niue, iá, Tah. \\
\hline Spear. & & ... & bele & ... & ... & taó & ... & ... & pere & $\ldots$ & N.B. orig. means reappear. \\
\hline Knot in & slin & $\ldots$ & burum & ... & .. & & & & purumu & ... & \\
\hline Breathe & $\ldots$ & $\cdot$ & ga & $\cdots$ & $\cdots$ & $\mathrm{ga}(\mathrm{Tu}$ & tuila) & $\cdots$ & ga & ... & gaé, mānava, Sam. \\
\hline Class or & $\operatorname{con}$ & ny & kaba & $\cdots$ & ... & & & & kapa & ... & very interesting. \\
\hline Dig & ... & $\ldots$ & kili & ... & ... & ele & $\cdots$ & .. & keri & $\ldots$ & \\
\hline Pluck & ... & $\cdots$ & $k$ uti & ... & $\cdots$ & futi & ... & ... & huti & ... & huti, Tah. \\
\hline Eye, fac & & ... & mata & $\ldots$ & $\ldots$ & mata & $\ldots$ & ... & mata & $\ldots$ & \\
\hline Grow & ... & ... & tubu & $\cdots$ & ... & tupu & ... & ... & tupu & ... & tupu, Tah. \\
\hline Turn ov & rer & $\cdots$ & buli & $\cdots$ & .. & fuli & $\cdots$ & ... & hưri & ... & \\
\hline Plait & $\ldots$ & ... & piri & $\cdots$ & $\ldots$ & fili & $\ldots$ & ... & whiri $\quad \ldots$ & ... & firi. \\
\hline Hear & $\cdots$ & .. & l̄ogoroỉ & $\cdots$ & $\ldots$ & logona & ... & ... & rogo & ... & fanogonoga, Niue. \\
\hline Die & $\cdots$ & $\cdots$ & mat & $\cdots$ & $\cdots$ & mate & $\cdots$ & $\cdots$ & mate & ... & mas, Aneiteum. \\
\hline Fly & $\cdots$ & $\cdots$ & lag & $\cdots$ & $\cdots$ & lago & $\cdots$ & $\cdots$ & rago, garo & ... & raó, Tah., inlag Aneiteum. \\
\hline Ship & $\cdots$ & $\cdots$ & parau & $\cdots$ & ... & folau & $\cdots$ & ... & & & $\{$ prahu $\}$ Malay. \\
\hline Rise up & $\cdots$ & ... & ragarag & gai & ... & lagalag & & $\cdots$ & ragai & ... & \\
\hline Lift & $\cdots$ & $\cdots$ & tiki & $\cdots$ & $\cdots$ & síi & $\cdots$ & $\cdots$ & tiki (fetch) & $\cdots$ & $\left\{\begin{array}{l}\text { nikitú Niue, Siki Fiji. } \\
\text { Tii. Tah., Hiki, Tong. }\end{array}\right.$ \\
\hline Land & $\cdots$ & $\cdots$ & wanua & $\cdots$ & $\cdots$ & fanua & $\cdots$ & $\cdots$ & whenua & ... & $\{$ fonua, Tah., benua enua, \\
\hline Female & $\cdots$ & $\ldots$ & wawine & & $\cdots$ & fafine & $\bullet \bullet$ & ・• & wahine & $\ldots$ & vahine, Tah., fefine, N.G. \\
\hline Tame & $\cdots$ & $\cdots$ & la & $\cdots$ & $\cdots$ & lata & $\cdots$ & ... & rarata ... & ... & rata, Tah. \\
\hline Sick & $\cdots$ & $\cdots$ & marua & $\cdots$ & $\cdots$ & luai & $\cdots$ & ... & ruaki ... & $\cdots$ & rual, Tah. \\
\hline First & $\cdots$ & $\cdots$ & muk:a & $\cdots$ & $\cdots$ & mua & $\cdots$ & $\cdots$ & matamua & $\cdots$ & mua, Tah. \\
\hline
\end{tabular}


Examples of Words in Slightly Altered form or Expressing Different Shades of Meaning.

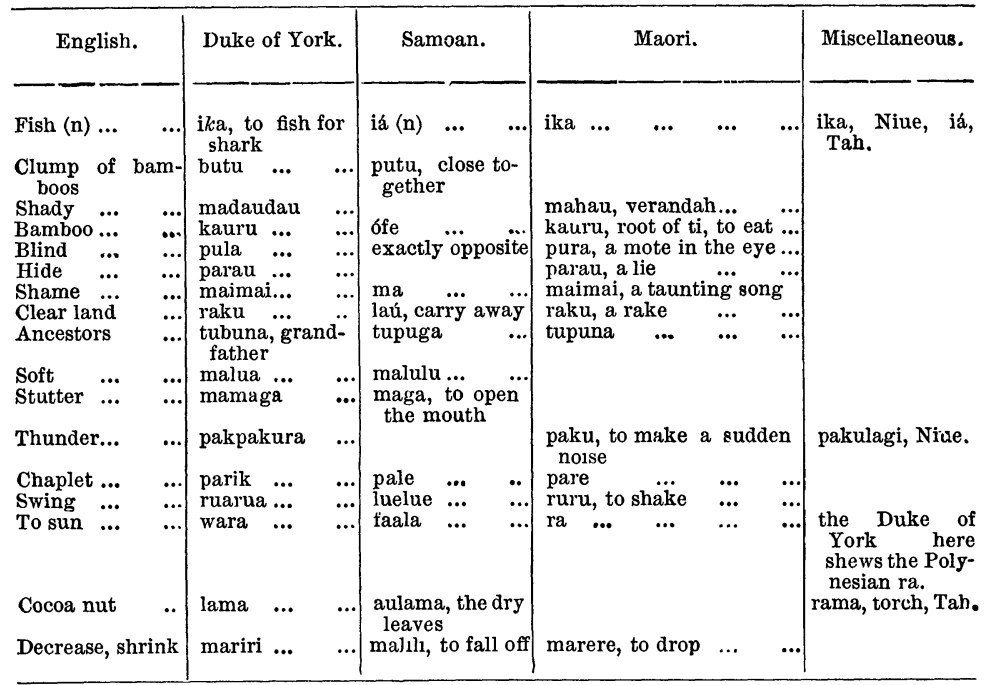

These examples will be sufficient to show that there is a great similarity not only in words which may have been floated in upon a language from outside sources, but also in the roots, particles, and words used in the different groups. Some of these, it will be seen, which are continually used in Papuan dialects are not found in Samoa, but appear again in groups still more remote from the present centre of the Papuan-speaking races, either expressing the same meaning, or some slightly different but analogous one. These root words and particles are a greater proof of the identity of different dialects than a much larger number of ordinary words of precisely similar form, or expressing the same shade of meaning.

Much stress has been laid upon the fact that no Polynesian language has any closed syllables. Every syllable must terminate with a vowel, and there can be no consonantal termination in any of its dialects. I niyself attached great importance to this at one time; but I have ceased to do so for some time, for the simple reason that whilst some Papuan dialects in the Western Pacific are full of closed syllables there are others which are equally full of open ones, and are in fact almost as vocalic as any Eastern Polynesian dialect, though the grammatical construction of the language is still Papuan. I have also noticed a great tendency in some of the Polynesian peoples to eliminate or cut very short indeed the sound of the final vowel 
in many words, and this I think is a survival of the closed sounds of the older Papuan. If then we can find a reasonable proof of the original identity of the languages in the similarity of the words and roots, and also in the grammatical construction of both, this fact of the open syllables of Polynesian dialects, as against the closed and open ones of the Papuan, will not I think present any serious difficulty.

By far the most serious difficulty has yet to be met; and this presents itself in the fact that the Papuan dialects are all distinguished by suffix formations, whilst the Polynesian is said to be distinguished by a preference for prefixes. But it may be questioned I think whether the Papuan is not almost as favourable as the Polynesian to prefixes; as also whether the Polynesian dialects of to-day, which are but slightly agglutinating, do not present many traces of suffix formations, which for some reason or other have, in many instances been exchanged for prefixes. I am well aware that in the opinion of many this will be regarded as a mark of degeneracy which the present advanced state of the Polynesian, as compared with the Papuan, does not render probable, but the fact I think remains. The Papuan, which is the older tongue, is distinguished by suffix formations, the Polynesian, which is a later branch of it, has been affected by outside influences which, whilst enriching the language in some way, have weakened it by diminishing the number and power of its pronominal suffixes and transitive terminations. It will be impossible in the time at my disposal to give anything like a complete comparison of the two languages. A few words on each must suffice. The Polynesian (Samoan) has fourteen letters ; the Papuan (Duke of York) has seventeen. In Samoan the article $l e$ is both definite and indefinite. And in the Duke of York, $a$ is the same. Se in Samoan is always indefinite and so is $t a$ in Duke of York. In both languages nouns are formed from verbs by the addition of terminal particles; in both the simple form of the verb may often be used as a noun, as to pray or a prayer. In both adjectives may be made into nouns by addition of the article, as lame, a lame man. In both gender is expressed by distinct names, or when the name is not sex-expressing, by adding the word male or female.

In both the singular number is expressed by its distinguishing adjective, the dual or trinal by numerals prefixed, and the plural is generally expressed by words expressive of quantity or number. In both, case is indicated by particles and prepositions. In the pronouns there appears to be at first a very great difference between the two, arising from the fact that in Papuan many nouns take a possessive pronominal suffix, whilst in Polynesian they only take the pronominal adjective before the 
noun. Passing by for the present the last assertion, which I venture to think requires some modification, I will simply notice a few facts which, if fairly considered, will tend I think to show that there are survivals in Polynesian of these Papuan suffixes, and that the great fundamental distinction between those pronouns used to express a passive or intransitive relation, and those used to express an active or transitive action obtain in both languages, and may fairly be considered as additional evidence in favour of the theory of the common origin of both.

1. Some nouns in Papuan which take a suffix may also have the pronoun prefixed, e.g., a r'umaig, my house, or a nug ruma.

2. All that class of nouns which in Samoa take $o$ and lona (implying a passive or intransitive relation), are the same class which in Papuan take the pronominal suffixes, whilst those which in Samoan take $\alpha$ and lana (implying an active and transitive relation), are those which in Papuan generally prefix the pronouns, evidently showing a generally underlying principle which is common to both of them.

3. The possessive termination in Samoa is undoubtedly a distinct word, as it is in the Duke of York ; lou, more, is really lo oú, yams; lou, lo ou; lona, his-lo na or lona, as lo matou, ours, \&c., and in lona mata, his eye, the $n \alpha$ is precisely the same word which suffixed to mata in Duke of York makes matana, with the same meaning.

4. But in addition to this there are not wanting other traces or survivals of the suffixes in Eastern Polynesian, where some nouns and verbs take a suffix to the principal noun or verb, which is, I think, the same as in Papuan; e.g., tupu, to grow, in Samoan, takes ga as a suffix, and forms tupuga, ancestors; and in Maori the same word takes $n \alpha$, and forms tupuna, ancestors. $N g$ and $n$ are interchangeable consonants, and clearly here express the same meaning, and few will doubt their agreement with the pronoun suffix $n a$ in many Papuan words, e.g., the Papuan tapuna or tupuna for grandfather. Many other examples might be given, which show that the suffix is retained in this form in the third person singular: but I do not at present remember any with the other numbers as in Papuan.

The formation of adjectives from nouns, the use of the simple form of the verb as an adjective, the prefixing of a particle signifying like, and the form of comparing adjectives are all alike in the two languages.

The numerals up to five are very much alike, and are in fact the same words, whilst the Duke of York has also separate words for the numbers up to ten, which are the same as in Polynesian, though they are only used in counting couples. Both peoples have a separate way of counting different articles. 
Both make free use of distributives, and it must be especially noticed that both use the same form of calling eight ten less two, and nine ten less one.

Papuan is, undoubtedly, richer in transitive terminations than is the Eastern Polynesian; but a more careful study of many of the so-called particles of Eastern Polynesian dialects, will show that many of them are really the old transitive terminations. I am also inclined to believe that the Polynesian is richer in transitive terminations than is generally known, whilst the suffixes tat and sat (and gâे?) in Samoan certainly change the action of the verb in precisely the same way that similar suffixes with the causative prefixed do in Papuan; e.g. moetai, to run with a thing, is wakalai in Duke of York.

But I must conclude for the present this part of my subject by a quotation from the Introduction to my Grammar and Vocabulary. "The points of similarity between the two languages, as in the construction and formation of nouns and adjectives, the existence of the dual number in both, and traces of the trinal in the Eastern Polynesian, as in Tonga and Samoa, the use common to all of inclusive and exclusive pronouns, the reciprocal and causative forms of the verbs, the formation of the passive, the use of transitive terminations, and many other points are neither few nor insignificant as pointing to a common origin of both languages." I hope at some future time to show that the opinion here advanced is strengthened if not confirmed by a comparison of the manners and customs of the different peoples and especially by the survivals in culture amongst the later Polynesians of the customs and traditions of their Papuan ancestors.

The following paper was read by the Secretary :-

Notes on Songs and Songmakers of some Australian Tribes.

By A. W. Howitr, F.G.S., Corr. Mem. Anth. Inst.

THE songs and dances of the Australian aborigines are usually spoken of by our own people as "corroborees," and this word is also even frequently applied to any of their social gatherings. This application is, however, not correct, for the songs, the song and dances, and the assemblies for social or other purposes have each their own distinctive name. The word "corroboree" has been adopted by the settlers from some tribal dialect in the early settled districts, probably of New South Wales, and has 